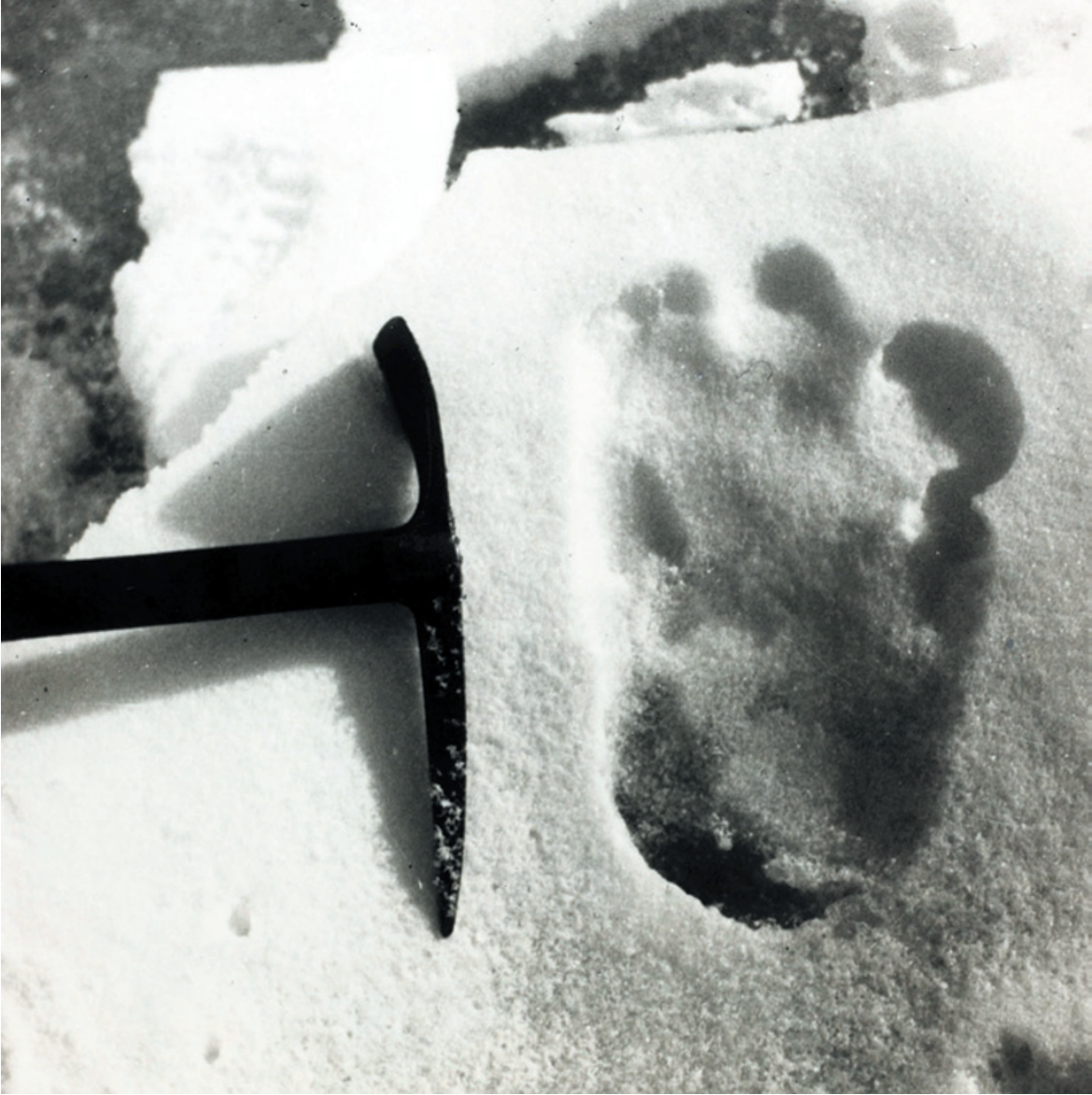

A purported yeti footprint from the Menlung Basin in Nepal.

\title{
CRYPTOZOOLOGY
}

\section{Beastly fakes}

\section{Daniel Cressey delves into a sceptics' history of monster hunters and their mythical quarry.}

\section{$\mathrm{T}$} he animals that star in Abominable Science! will be known to most children. Sadly, none of them exist. Daniel Loxton, a journalist for Skeptic science magazine, and palaeontologist Donald Prothero dedicate their engaging book to chronicling how we arrived at a point at which, despite a huge absence of evidence, people still believe in cryptids such as the yeti, the Loch Ness monster, sea serpents and the 'Congo dinosaur' (Mokele Mbembe), a purported living sauropod.

What emerges is a never less than rigorous examination of the evidence, and a cultural history of cryptozoology. Loxton and Prothero, who take it in turns to pen chapters, have a grudging respect for some of the characters who populate this bizarre world of monster hunters, if more for their doggedness than their scientific precision. They point out that a number of real animals, such as the okapi and mountain gorilla, have been discovered after scientists investigated the stories of locals and vague reports of sightings. "The distinction between cryptozoology and conventional

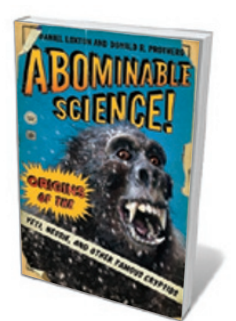

Abominable Science! Origins of the Yeti, Nessie, and Other Famous Cryptids

DANIEL LOXTON AND DONALD R. PROTHERO Columbia University Press: 2013. biology is not necessarily very big," they write, before comprehensively documenting that 'necessarily' is a key caveat.

Some hunters of Bigfoot, or Sasquatch, the gigantic primate that supposedly stalks the forests of North America, do seem to behave like biologists. A less kind interpretation would be that they adopt the trappings of science, but ignore its philosophy. As Loxton and Prothero demonstrate, the hunters' behaviour would appal most rightthinking field researchers. The title of the book says it all.

Each chapter follows a similar pattern, starting with an early pioneer combining some folk tales with a vague sighting of something in the distance. This is generally followed by other people faking evidence, until a self-reinforcing legend is established. As more monster hunters flock to find the beast, more dubious evidence is generated. Before you know it, there is a souvenir shop selling T-shirts.

Yet it is the hunters - ranging from outright rogues to serious, if misguided, researchers - who make this a gripping read. For instance, Bernard Heuvelmans, referenced as the founder of modern cryptozoology, earned a doctorate studying aardvark teeth, worked as a jazz musician and comedian, escaped from the Nazis and befriended Tintin creator Georges Prosper Remi (known by the penname 'Hergé') before producing his work on cryptids of all kinds.

On a 1958 expedition to Tibet to seek the yeti (a kind of Himalayan Bigfoot), led by Texas oil baron
"What emerges is anever less than rigorous examination of the evidence." Tom Slick, some members of the group allegedly performed sleight of hand on a sacred relic, swapping human finger bones for purported yeti bones. The stolen bones were reportedly smuggled out of the country in the luggage of actor James Stewart.

Going by these and other anecdotes in Abominable Science! - such as people strapping on fake wooden feet to create 'Sasquatch' tracks - the book could justifiably have been a compilation of mockery and humour. In fact, it is a sensitive but devastating takedown of an entire subculture. It culminates in a final chapter that poses a puzzling question: why do people believe in monsters, in a world under surveillance by satellites and camera-toting hikers? No credible photograph of any of these creatures has ever been captured.

Rather unsatisfactorily, Loxton and Prothero fail to pin down the answer to this question. Instead, they end up detailing the damage pseudoscience can do, and suggesting how cryptid hunting could become a genuine science, contributing to "a world somewhat less ignorant and anti-scientific than the one in which we grew up". On the basis of the information they present, however, it seems probable that true believers in such tall tales will always be with us. Evidence - or the lack of it - is never enough to scupper a good story. At least Abominable Science! proves that proper examination of it can produce an equally compelling tale.

Loxton admits that as a child, he believed in the things he now debunks. His passion eventually led him to question what he was told, and to co-author this book. Hopefully it will encourage others to take a similar journey.

Daniel Cressey is a reporter for Nature. 